Indonesian Journal of Biotechnology, June, 2013

Vol. 18, No. 1, pp.70-74

\title{
The Application of Polymerase Chain Reaction - Restriction Fragment Polymorphisms (PCR-RFLP) to Determine Genetic Diversity of Madura Cattle in Sapudi Island
}

\author{
Tety Hartatik ${ }^{1 *}$, Slamet Diah Volkandari ${ }^{1}$, Sumadi $^{1}$, and Widodo ${ }^{1,2}$
}

\author{
${ }^{1}$ Faculty of Animal Science, Universitas Gadjah Mada, Yogyakarta, Indonesia. \\ ${ }^{2}$ Research Center for Biotechnology, Universitas Gadjah Mada, Yogyakarta, Indonesia
}

\begin{abstract}
The aim of this study was to determine genetic diversity of Madura cattle using Polymerase Chain Reaction - Restriction Fragment Length Polymorphisms (PCR-RFLP) analysis of the cytochrome b (cytb) gene. Samples used for the experiments were blood of 43 cattle that consist of 15 cattle obtained from Madura Island, 23 cattle from Sapudi Island, and 5 Limousin-Madura (Limura) cattle. A fragment of 464 base pair of cytb gene was amplified by forward primer L14735 and reverse primer H15149. The PCR product was digested with TaqI and Hinfl restriction enzymes to identify genetic patterns. Data of PCR-RFLP showed two haplotypes, that were $\mathrm{A}$ and $\mathrm{B}$, in cattle obtained from both Madura Island and Sapudi Island. The frequencies of haplotype A and B of cattle from Sapudi Island were $69.57 \%$ and $30.47 \%$, respectively. More diverse frequencies were observed in cattle obtained from Madura Island, where haplotype A and B were $86.67 \%$ and $13.33 \%$, respectively. In this experiment, Limura cattle had only haplotype A. As a conclusion, PCR-RFLP of the cytb gene had been able to determine a genetic diversity of Madura cattle.
\end{abstract}

Key words: Genetic diversity, Madura cattle, haplotype.

\section{Introduction}

Madura cattle are local cattle used to be work animals, bull race (Karapan), art contest (Sonok) and beef cattle. Madura cattle have uniform in shape and are stable inbred hybrid between Zebu (Bos indicus) and Banteng (Bos javanicus). The uniformity of the breed was developed through selection for many years by local people in Madura. Physically, the color of the cattle is reddish brown with nonspecific white pattern on the back and rump. In 2002, the population was estimated of around 900,000 cattle. Efforts are now being made to conserve cattle breed on Sapudi Island, as this is a conservation place for Madura cattle, where only the original Madura cattle are allowed

\section{*Corresponding author :}

Tety Hartatik

Faculty of Animal Science, Universitas Gadjah Mada, Jl. Fauna, Bulaksumur, Yogyakarta, Indonesia. E-mail: tetyharuta@yahoo.com to live in that area. Non-Madura cattle from outside Sapudi Island are not permitted to entry and live in this area (Umar et al, 2011; Widi et al, 2010)

Cattle variety is configurated from native cattle with that of genetically-imported resources. Madura cattle are a combination of Bali-Ongole-Java native composite breed, developed from Bali (Bibos banteng), Javanative (Bos javanicus) and Ongole (Bos indicus). Nijman et al. (2003) reported that DNA of Madura cattle are mixture of DNA from both Zebu cattle and Banteng. Meanwhile, crossbreeding between Limousin bull and Madura cows by artificial insemination (AI) has produced Limura cattle. The exterior characteristic of Limura cattle show diversity on phenotypes as this was produced by a combination of both parental breed.

Mitochondrial DNA (mtDNA) is an extra-nuclear DNA that has been proven to be a useful molecular marker for evolutionary 
studies in animal populations due to its predominantly maternal inheritance, relatively rapid base substitution rate, and lack of recombination (Avise et al. 1987). Mitochondrial DNA contains more sequence diversity compared to that of nuclear DNA (Brown et al., 1996). Analysis of Polymerase Chain Reaction-Restriction Fragment Length Polymorphism (PCRRFLP) has been successfully applied to amplify the target sequence. Nijman et al. (2003) employed PCR-RFLP technology to analyze hybridization between banteng (Bos javanicus) and Zebu (Bos indicus) in Southeast Asia using mitochondrial DNA and to identify the nucleotide polymorphisms in the 359 base pair of mitochondrial gene cytochrome b (Cytb) Iberian cattle (Bos taurus) (Prado et al., 2005). Cytochrome b gene of several vertebrates, including mammals, had been used to investigate evolutionary and genetic diversity and molecular phylogenetic studies (Wolf et al., 1999). In this study, $C y$ tb gene was employed to evaluate genetic diversity of Madura cattle in Sapudi Island.

\section{Materials and Methods Blood samples and DNA extraction}

Blood samples was collected from 43 cattle, consist of 15 Madura cattle from Madura Island, 23 Madura cattle from Sapudi Island, and 5 Limura cattle. Samples were prepared for DNA isolation by using a KIT high pure PCR template preparation (ROCHE) according to the protocol. Ear tissues were prepared by using standard SDS/ProteinaseK method according to Sambrook et al. (1989).

\section{Polymerase Chain Reaction (PCR)}

A fragment of 464 base pair of cytochrome $b$ gene was amplified using both forward primer of L14735 (5'-AAA AAC CAC CGT TGT TAT TCA ACT A-3') and reverse primer of H15149 (5'-GCC CCT CAG AAT GAT ATT TGT CCT CA-3') (Wolf et al., 1999). PCR was carried out in a final volume of 20 $\mu \mathrm{l}$ reaction mixture containing $1 \mu \mathrm{l}$ sample
DNA (10-100 ng), $1 \mu$ l each primer, $10 \mu l$ PCR KIT (Fastart, Roche), and $7 \mu$ aquabidest. The amplification process was performed using Thermocycler (Infinigen, TC-25/H). Amplifications were performed under the following conditions: initial denaturation at $94^{\circ} \mathrm{C}$ for $2 \mathrm{~min}$, followed by 35 thermal cycles of denaturation at $95^{\circ} \mathrm{C}$ for $36 \mathrm{sec}$, annealing at $51^{\circ} \mathrm{C}$ for $73 \mathrm{sec}$, and extension at $72^{\circ} \mathrm{C}$ for $84 \mathrm{sec}$. The final extension was performed at $72^{\circ} \mathrm{C}$ for $3 \mathrm{~min}$ (Prado et al., 2005). PCR products were visualized on $1 \%$ agarose gels buffered with 1X Tris-Boric-EDTA (1X TBE), stained with ethidium bromide, and visualized under UV light. To get the DNA sequence of PCR product, we performed DNA sequencing by Macrogen.

\section{Restriction Fragment Length Polymorphism (RFLP)}

PCR products was digested by restriction enzymes as described previously (Verkaar et al., 2002). The 464 bp amplicon was digested with TaqI and Hinfl restriction enzymes to identify genetic patterns. A volume of $3 \mu \mathrm{l}$ PCR product was digested with 1U Hinfl enzyme in Tango buffer at $37^{\circ} \mathrm{C}$ for $3 \mathrm{~h}$ (Fermentas) and followed by digestion with $1 \mathrm{U}$ Taq I enzyme at $65^{\circ} \mathrm{C}$ for $2 \mathrm{~h}$. The digestion product was separated on $12 \%$ polyacrylamide gels at $50 \mathrm{~V}$ for $3 \mathrm{~h}$. The gel was stained gently by ethidium bromide and visualized under UV light. The size of DNA fragments were compared to the DNA marker $\Phi$ X174 DNA/BsuRI (HaeIII), (Fermentas).

\section{Results and Discussion}

To obtain genetic patterns, the amplified 464 base pair of DNA fragment of the Cytb gene from all of samples collected from 43 cattle was subjected to RFLP analysis. The data showed that there were two haplotypes observed in cattle obtained either from Madura Island and Sapudi Island, while the Limura cattle had only haplotype A (Figure 1 and 2). The amplification of both haplotypes with mitochondrial-specific primers L14735 
and $\mathrm{H} 15149$ revealed the presence or absence of restriction sites for Hinfl and TaqI enzymes. Using Hinfl as restriction enzyme, haplotype A was observed as shown by two bands of 305 and 159 base pairs and haplotype B was observed as shown by three bands of 198, 149 and 117 base pairs (Figure 1). Meanwhile, using Taq1 as restriction enzyme, haplotype A was observed as shown by two bands, namely 225 and 191 base pairs, and haplotype B was observed by one band of 416 base pair (Figure 2).

The specific haplotype of Madura cattle was shown in Table 1.The frequencies of haplotype A and haplotype B of cattle obtained from Sapudi Island were $69.57 \%$ and $30.47 \%$, respectively. Those frequencies were less diverse then that obtained from cattle of Madura Island where haplotype A and $B$ were $86.67 \%$ and $13.33 \%$, respectively. This data suggests that cattle from Sapudi Island were genetically closer compared with

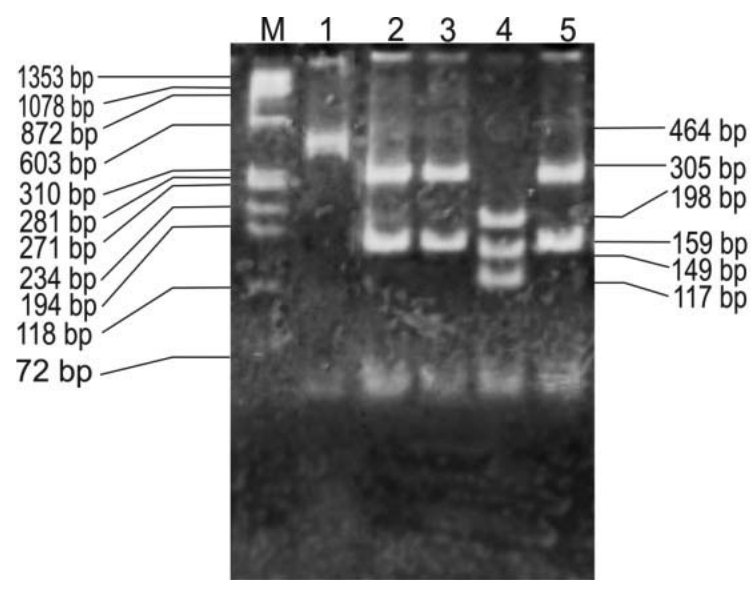

Figure 1. Restriction pattern of enzyme HinfI. M: marker (ФX174 DNA/BsuRI (HaeIII), lane 1: PCR product (464 bp) as a negative control, lane 2,3,5: Haplotype A and lane 4: Haplotype B that in Madura Island. We also observed that $100 \%$ of Limura cattle had only haplotype A (Table 1). The RFLP data reported here were similar with that of previous experiment (Wolf et al., 1999), suggesting the accuracy of PCR-RFLP in determining genetic patterns.

Wolf et al (1999) suggested that to distinguish between species, amplified bands of specific PCR products were digested with different restriction endonucleases enzymes, and his could resulting in a species-specific RFLP. They proved that even closely related animal species was able to be distinguished by application of one or two restriction endonucleases enzymes. The differences on haplotype frequencies indicated a genetic diversity. In this study, cattle in Sapudi Island had only a single species that were divided into two haplotype patterns. Interestingly, PCR-RFLP of Cytb gene of mtDNA using Hinf I and TaqI enzymes could potentially be used as molekuler

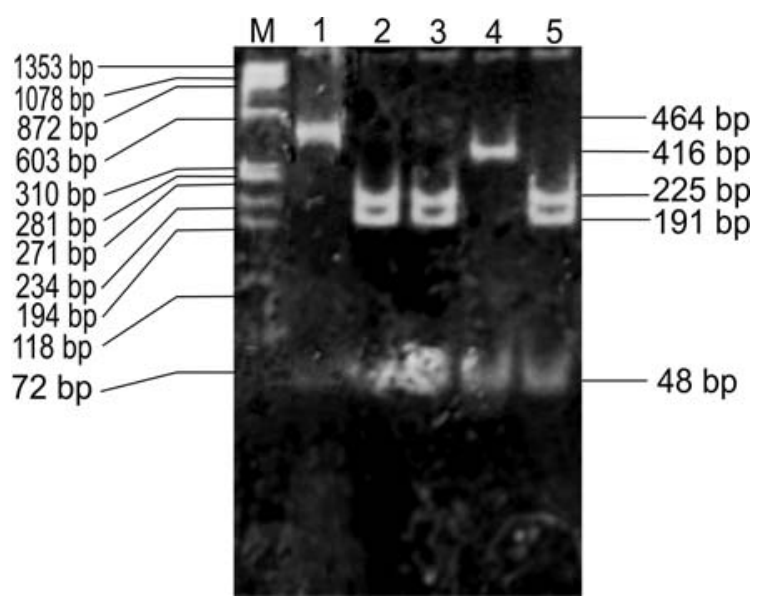

Figure 2. restriction pattern of enzyme TaqI. M: marker (ФX174 DNA/BsuRI (HaeIII), line 1: PCR product (464 bp) as a negative control, line 2,3,5: Haplotype A and 4: Haplotype B

Table 1. Haplotype frequencies of Madura and Limura cattle based on location

\begin{tabular}{llcccccc}
\hline \multirow{2}{*}{ Breed } & \multirow{2}{*}{ Location } & $\mathrm{n}$ & \multicolumn{2}{c}{ Haplotypes } & \multicolumn{2}{c}{ Haplotypes (\%) } \\
\cline { 4 - 7 } & & & $\mathrm{A}$ & $\mathrm{B}$ & $\mathrm{A}$ & $\mathrm{B}$ \\
\hline Madura & Madura island & 15 & 13 & 2 & 86.67 & 13.33 \\
Madura & Sapudi island & 23 & 16 & 7 & 69.57 & 30.47 \\
Limura & Madura island & 5 & 5 & - & 100 & - \\
\hline
\end{tabular}




\begin{tabular}{|c|c|c|c|c|c|c|c|c|c|c|c|c|c|c|c|c|c|c|c|c|c|c|c|c|c|c|c|c|c|c|c|c|}
\hline SNP site & 1 & 2 & 3 & 4 & 5 & 6 & 7 & 8 & 9 & 10 & 11 & 12 & 13 & 14 & 15 & 16 & 17 & 18 & 19 & 20 & 21 & 22 & 23 & 24 & 25 & 26 & 27 & 28 & 29 & 30 & 31 & 32 \\
\hline JO13394 & $\mathrm{T}$ & C & $\mathrm{C}$ & A & $\mathrm{T}$ & $\mathrm{T}$ & A & A & $\mathrm{T}$ & $\mathrm{A}$ & C & $\mathrm{C}$ & $\mathrm{A}$ & $\mathrm{C}$ & $\mathrm{C}$ & $\mathrm{T}$ & C & $\mathrm{C}$ & $\mathrm{C}$ & $\mathrm{C}$ & $\mathrm{T}$ & $\mathrm{T}$ & $\mathrm{C}$ & $\mathrm{T}$ & $\mathrm{T}$ & $\mathrm{T}$ & $\mathrm{T}$ & $\mathrm{G}$ & $\mathrm{C}$ & $\mathrm{T}$ & $\mathrm{C}$ & C \\
\hline SP2 & C & $\mathrm{T}$ & $\mathrm{T}$ & $\mathrm{G}$ & C & C & $\mathrm{G}$ & & C & G & A & $\mathrm{T}$ & $\mathrm{G}$ & $\mathrm{T}$ & $\mathrm{T}$ & C & $\mathrm{T}$ & $\mathrm{T}$ & $\mathrm{T}$ & $\mathrm{T}$ & C & C & & C & C & C & . & $\mathrm{A}$ & $\mathrm{T}$ & C & $\mathrm{T}$ & A \\
\hline $\mathrm{SP} 3$ & $\mathrm{C}$ & $\mathrm{T}$ & $\mathrm{T}$ & $\mathrm{G}$ & C & C & $\mathrm{G}$ & & C & $\mathrm{G}$ & A & $\mathrm{T}$ & $\mathrm{G}$ & $\mathrm{T}$ & $\mathrm{T}$ & C & $\mathrm{T}$ & $\mathrm{T}$ & $\mathrm{T}$ & $\mathrm{T}$ & C & C & & $\mathrm{C}$ & C & $\mathrm{C}$ & & $\mathrm{A}$ & $\mathrm{T}$ & C & $\mathrm{T}$ & A \\
\hline SP4 & $\mathrm{C}$ & $\mathrm{T}$ & $\mathrm{T}$ & $\mathrm{G}$ & C & $\mathrm{C}$ & $\mathrm{G}$ & & $\mathrm{C}$ & G & $\mathrm{A}$ & $\mathrm{T}$ & $\mathrm{G}$ & $\mathrm{T}$ & $\mathrm{T}$ & C & $\mathrm{T}$ & $\mathrm{T}$ & $\mathrm{T}$ & $\mathrm{T}$ & $\mathrm{C}$ & C & & $\mathrm{C}$ & C & $\mathrm{C}$ & & $\mathrm{A}$ & $\mathrm{T}$ & $\mathrm{C}$ & $\mathrm{T}$ & A \\
\hline SP7 & & & . & & . & & & $\mathrm{G}$ & & . & . & & . & ${ }^{\circ}$ & . & . & . & . & & . & . & & $\mathrm{T}$ & . & . & & C & . & . & $\mathrm{C}$ & & . \\
\hline SP13 & . & . & . & . & . & . & . & $\mathrm{G}$ & . & . & . & & . & - & . & . & - & . & . & . & 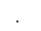 & 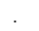 & $\mathrm{T}$ & 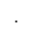 & . & - & $\mathrm{C}$ & 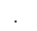 & - & $\mathrm{C}$ & . & . \\
\hline SP14 & . & . & 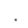 & & & . & . & G & & & & & . & . & . & & & - & . & . & . & . & $\mathrm{T}$ & . & . & . & C & . & . & $\mathrm{C}$ & . & . \\
\hline
\end{tabular}

Figure 3. Sequence Aligment of $c y t b$ of $m t D N A$ of cattle in Sapudi Island

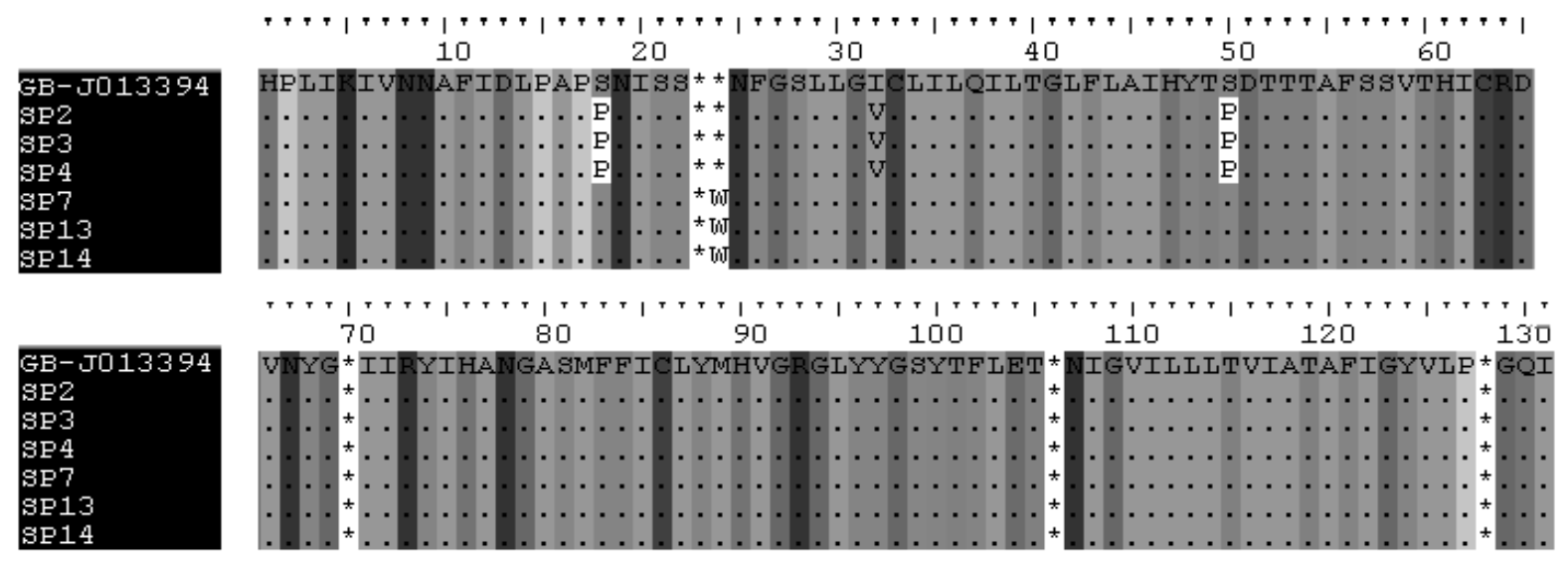

Figure 4. Amino acid differences of $c y t b$ of mtDNA of cattle in Sapudi Island

marker for identification of genetic diversity cattle in Sapudi Island.

Further analysis showed that Madura cattle in Sapudi Island had 32 single nucleotide polymorphisms (SNPs) and 4 different amino acid in 395 base pairs sequence of cytb gene (Figure 3 and 4). Of the nucleotide polymorphisms observed, included were differences from $T$ to $C$ (12 sites), from $C$ to $T$ (12 sites), from $A$ to $G$ ( 5 sites), from $C$ to $A$ ( 2 sites), and from $G$ to $A$ (1 site) (Figure 3).

Meanwhile, Figure 4 showed amino acid differences as a consequence of differences on nucleotide sequences. As can be seen in Figure 4, amino acid sequence number 18 had changed from Serine (TCA) to Proline (CCA), meanwhile amino acid number 22 had also changed from stop codon (TGA) to Tryptophan (TCC). Another amino acid differences were also observed in sequence number 31 from Isoleucine (ATC) to Valine (GTA), and sequence number 50 from Serine (TCC) to Proline (CCC) (Figure 4). Differences on both nucleotides and amino acid sequence strongly suggesting any genetic diversity in cattle from Sapudi Island. As this island is restricted area for any other cattle breeds, the less genetic diversity of cattle observed is of understandable. In this case, Sapudi Island is one of best practice in conserving genetic of Madura cattle in Indonesia.

\section{Acknowledgement}

The authors would like to thank the Faculty of Animal Science, Universitas Gadjah Mada which has provided research funding through the Research Grant for the year 2010.

\section{References}

Avise J. C., Arnold, J., Ball, R. M., Bermingham, E., Lamb, T., Neigel, J. E., Reeb, C. A. and Saunders, N. C. 1987 Intraspecific phylogeography: the mitochondrial DNA bridge between population genetics and systematics. Annu. Rev. Ecol. Syst. 18, 489-522.

Brown, J. R., K., Beckenbach, A. T., and M. J. Smith. 1996. Length variation, heteroplasmy and sequence divergence in the mitochondrial DNA of four species of sturgeon (Acipenser). Genetics, 142, 525-35. 
Nijman, I. J., Otsen, M., Edward, LC. Verkaar, L.C., Christa de Ruijter, Hanekamp,E., Ochieng, J.Y., Shamshad,S.B.M., Edward O.R., Hanotte, O., Barwegen, M.W., Sulawati , T., dan Lenstra, J.A., 2003, Hybridization of Banteng (Bos Javanicus) and Zebu (Bos Indicus) Revealed by Mitochondrial DNA, Satelite DNA, AFLP, and microsatelite. HEREDITY, 90, 10 - 16.

Prado, M., Calo, P., Cepeda, A., and BarrosVelázquez,J. 2005. Genetic evidence of an Asian background in heteroplasmic Iberian cattle (Bos taurus): Effect on food authentication studies based on polymerase chain reaction-restriction fragment length polymorphism analysis. Electrophoresis, 26, 2918-2926.

Sambrook, J., Fritsch E. F. and Maniatis T. (1989). Molecular Cloning, A Laboratoty Manual. Cold Spring Harbour Laboratory Press: Cold Spring Harbour, USA.

Umar, M., Arifin, M., and Purnomohadi, A. 2011. Ruminal condition between madura cattle and ongole crossbred cattle raised under intensive feeding. J. Indonesian Trop. Anim. Agric., 36(3)

Verkaar, E.L.C., Nijman, I.J.,Boutaga, K., Lenstra, J.A. 2002. Differentiation of cattle species in beef by PCR-RFLP of mitochondrial and satellite DNA. Meat Science, 60, 365-369

Widi, T.S.M., Hartatik, T., and Udo, H. 2010. Traditional Art Contest of Sonok as an Alternative for Selection of Good Quality of Madura Cattle. Proceeding Tropentag 2010 "World Food System-A Contribution from Europe" September 14-16, Zurich, Germany

Wolf, C., Rentsch, J., and Hubner, P. 1999. PCR-RFLP Analysis of Mitochondrial DNA: A Reliable Method for Species Identification. J. Agric. Food Chem., 47, 1350-1355. 